\title{
MOLECULAR GENETIC AND LABORATORY FINDINGS IN INFERTILE MEN WITH NON-OBSTRUCTIVE AZOOSPERMIA
}

\author{
Kamal Z. Shaeer, MD*; Essam Nada, MD**; Ramadan Saleh, MD**; Manal O. El \\ Hamshary, PhD***; Ashraf A. Abd El-Latif, MSc**. \\ * Department of Andrology, Sexology and STIs- Faculty of Medicine- Cairo University; \\ ** Department of Dermatology, Venereology and Andrology- Faculty of Medicine- Sohag \\ University;*** Department of Molecular Diagnostics and Therapeutics- Genetic \\ Engineering and Biotechnology Research Institute- Sadat City University.
}

\begin{abstract}
Objectives:To study therelationship between Y-chromosome microdeletions withclinicaland laboratory findings in infertile men with non-obstructive azoospermia (NOA).

Design: Cross-sectionalstudy.

Patients: Infertile men withnon-obstructive azoospermia $(n=146)$.

Methods: Clinical evaluation and scrotal colour Doppler ultrasonography were evaluated. Standard semen analysis andserum levels of hormones(FSH, LH, total testosterone and prolactin) were performed. Multiplex PCR was done for detection of $\mathrm{Y}$ chromosome microdeletions.

Results:AZF deletions were detected in $9.59 \%$ of azoospermic men.CompleteAZFc was detected in $2.05 \%$ of azoospermic men.Partial AZFc deletions were found in $7.5 \%$ of azoospermic men, with gr/gr deletion in $6.85 \%$ and b2/b3 deletion in $0.69 \%$. There was no significant difference between patients with AZF deletions and azoospermic men without deletions as regards testicular volume and serum levels of reproductive hormones.

Conclusions:Microdeletions of Y chromosome may play a role in pathogenesis of NOA. The testicular volumes as well as levels of reproductive hormoneswere not correlated with the finding of $\mathrm{Y}$ chromosome microdeletions.
\end{abstract}

Key words: non-obstructive azoospermia, Y chromosome microdeletion, testicular biopsy.

\section{INTRODUCTION}

Azoospermia is defined as the absence of spermatozoa in the ejacula te, after analysis of a centrifuged specimen and such evaluation should be repeated on at least 2 occasions. This condition affects approximately $1 \%$ of men in the general population, and $10 \%$ to $15 \%$ of infertile men ${ }^{(1,2)}$. The cause ofazoospermia, whether secondary to spermatogenic failure or to obstruction of the excurrent ducts of the testis, is a key determinant of the management of these patients ${ }^{(3)}$. At least $15 \%$ of cases with NOA are related to genetic disorders, including both chromosomal and single-gene alterations ${ }^{(4)}$.

Microdeletions of $\mathrm{Y}$ chromosome are the second most frequent genetic cause of NOA after ${ }^{(\mathbf{5})}$.Azoospermia Factor (AZF)has been identified on the long arm of the $\mathrm{Y}$ chromosome and is subdivided into three regions, $\mathrm{AZFa}, \mathrm{AZFb}$, and $\mathrm{AZFc}^{(6)}$.The overall frequency of $\mathrm{Y}$ chromosome microdeletions varies from 1 to $55 \%$ in the different published studies ${ }^{\text {(7- }}$ 9).The most frequent deletion type is the AZFc region deletion ${ }^{(10)}$.

Identification of AZF deletion can provide valuable prognostic information. Complete deletions of the AZFa or $\mathrm{AZFb}$ regions indicate that finding sperm at the time of testicular sperm extraction (TESE) is impossible, whereas deletions in AZFc indicated a $50 \%$ possibility of finding sperm on microTESE ${ }^{(\mathbf{1 1})}$. Testing of Yq microdeletions should be offered for 
infertile men undergoing intra-cytoplasmic sperm injectionto rule out the possibility of transmission of $\mathrm{Y}$ microdeletions to their male offspring ${ }^{(\mathbf{1 2})}$.

The objective of this study was toevaluate theclinicaland laboratory findings in relation to AZF deletions in infertile men with nonobstructive azoospermia (NOA).

\section{PATIENTS AND METHODS:}

\section{1) Semen analysis:}

Semen analysis was performed according to World Health Organization 2010 guidelines $^{\mathbf{( 1 3})}$. Azoospermiawas defined as complete absence of spermatozoa even after centrifugation at $3000 \mathrm{~g}$ for 15 minutes for at least 2 times, 2 weeks apart.

\section{2) Hormonal profile:}

Venous blood sample was drawn from the Thisstudy included 146 infertile men with cubital vein in the morningand was NOAattending Andrology clinic at Sohag incubated at $37^{\circ} \mathrm{C}$ water bath for 10 University Hospitals. The study was approved minutes, and centrifuged at $3000 \mathrm{~g}$ for 10 by Ethical and Research committees at minutes. Serum levels of follicle stimulating Faculty of Medicine, Sohag University. All hormone (FSH), luteinizing hormone (LH), patients assigned an informed written total testosterone and prolactin were consent.

\section{Exclusion criteria:}

Patients having numerical chromosomal anomalies and those with evidence of varicoceleor obstruction of seminal tract were excluded. Exclusion criteria also included patients with history of testicular maldescent, genital infection, trauma, testicular torsionor treatment with chemotherapeutic agents or radiotherapy.

Methods: Patients were evaluated as follow:

I- Initial evaluation:Personal data (age, residency and occupation) and marital history were obtained from all patients. The family history regarding the fertility status of the relatives was reported. General examination was done to detect features of hypogonadism. Genital examination was performed to detect abnormality of penis, testes or epididymis or spermatic cord. Scrotal colour Doppler ultrasonography was performed for all patients.

\section{II- Laboratory investigations:}

\section{RESULTS}

The mean age \pm SD of the patients was $35.12 \pm 6.1$ years, with $75(51.4 \%)$ of them from urban areas. The mean duration of marriage \pm SD of theinfertile patients was $5.60 \pm 3.96$ years. The mean volume $\pm \mathrm{SD}$ of the right testis was $11.29 \pm 2.85 \mathrm{ml}$ and that of the left testis was $10.17 \pm 2.87 \mathrm{ml}$. The mean serum level \pm SD of hormones were FSH $(21.89 \pm$ $10.23 \mathrm{mIU} / \mathrm{ml}), \mathrm{LH}(14.12 \pm 6.19 \mathrm{mIU} / \mathrm{ml})$, testosterone $(5.38 \pm 1.37 \mathrm{ng} / \mathrm{ml})$, and prolactin $(6.88 \pm 1.60 \mathrm{ng} / \mathrm{ml})$.

Micodeletionsof $\mathrm{Y}$ chromosome were found in 14 of the 146 azoospermic patients (9.59\%). CompleteAZFc was detected in $2.05 \%$ and partial AZFc deletions were found in $7.54 \%$ of azoospermic men, with gr/gr deletion in $6.85 \%$ and b2/b3 deletion in $0.69 \%$. 
The study populations were classified according to results of microdeletions into two groups: azoospermic men with positive microdeletion $(n=14)$ and azoospermic men with negative microdeletion $(n=132)$. The demographic data of the study groups are shown in table 1.The clinical and laboratory data in the study groups are shown in table 2 .

Table 1: Demographic data in the study population $(n=146)$.

\begin{tabular}{|c|c|c|c|c|}
\hline \multicolumn{2}{|l|}{ Item } & $\begin{array}{l}\text { Azoospermic men } \\
\text { with positive } \\
\text { microdeletion } \\
(n=14)\end{array}$ & $\begin{array}{l}\text { Azoospermic men } \\
\text { with negative } \\
\text { microdeletion } \\
(\mathrm{n}=132)\end{array}$ & $* P$ value \\
\hline \multicolumn{2}{|c|}{ Age (years) } & $36.6 \pm 5.9$ & $34.2 \pm 6.5$ & $\mathbf{0 . 1 7}$ \\
\hline \multirow{2}{*}{$\begin{array}{l}\text { Resid } \\
\text { ence }\end{array}$} & Urban & $6(43 \%)$ & $69(52.3 \%)$ & \multirow{2}{*}{0.51} \\
\hline & Rural & $8(57 \%)$ & $63(47.7 \%)$ & \\
\hline \multirow{4}{*}{$\begin{array}{l}\text { Occupa } \\
\text { tion }\end{array}$} & Employee & $2(14.3 \%)$ & $30(22.7 \%)$ & \multirow{4}{*}{0.96} \\
\hline & Farmer & $4(28.6 \%)$ & $47(35.6 \%)$ & \\
\hline & Worker & $7(50 \%)$ & $51(38.6 \%)$ & \\
\hline & Others & $1(7.1 \%)$ & $4(3 \%)$ & \\
\hline \multicolumn{2}{|c|}{$\begin{array}{l}\text { Duration of current } \\
\text { marriage (years) }\end{array}$} & $5.43 \pm 2.34$ & $5.65 \pm 4.46$ & 0.77 \\
\hline \multicolumn{2}{|c|}{$\begin{array}{l}\text { Family history of } \\
\text { infertility }\end{array}$} & $1(7.1 \%)$ & $10(7.6 \%)$ & 0.64 \\
\hline
\end{tabular}

$* \mathrm{P}$ value $<0.05$ was considered significant.

Table 2: Clinical and laboratory data in the study population $(n=146)$.

\begin{tabular}{|c|c|c|c|c|}
\hline \multicolumn{2}{|l|}{ Item } & $\begin{array}{l}\text { Azoospermic men } \\
\text { with positive } \\
\text { microdeletion } \quad(n= \\
\text { 14) }\end{array}$ & $\begin{array}{l}\text { Azoospermic men } \\
\text { with negative } \\
\text { microdeletion } \\
(\mathrm{n}=132)\end{array}$ & $\begin{array}{l}* P \\
\text { value }\end{array}$ \\
\hline \multirow{2}{*}{$\begin{array}{l}\text { Testicular } \\
\text { volume } \\
(\mathrm{ml})\end{array}$} & Right testis & $11.71 \pm 1.44$ & $10.80 \pm 3.13$ & 0.62 \\
\hline & Left testsis & $10.43 \pm 1.70$ & $9.92 \pm 3.10$ & 0.35 \\
\hline \multirow{4}{*}{$\begin{array}{l}\text { Hormona } \\
\text { l profile }\end{array}$} & FSH $(\mathrm{mIU} / \mathrm{ml})$ & $21.29 \pm 7.27$ & $22.5 \pm 11.04$ & 0.69 \\
\hline & LH (mIU/ml) & $14.26 \pm 4.83$ & $14.08 \pm 6.57$ & 0.92 \\
\hline & $\begin{array}{l}\text { Testosterone } \\
(\mathrm{ng} / \mathrm{ml})\end{array}$ & $5.38 \pm 1.39$ & $5.39 \pm 1.41$ & 0.98 \\
\hline & $\begin{array}{l}\text { Prolactin } \\
\text { (ng/ml) }\end{array}$ & $7.07 \pm 1.62$ & $6.77 \pm 1.90$ & 0.52 \\
\hline
\end{tabular}

$* \mathrm{P}$ value $<0.05$ was considered significant.

\section{DISCUSSION}

The Y chromosome Microdeletions are the second most frequent genetic cause of male infertility ${ }^{{ }^{(5)}}$.A correlation between $\mathrm{Y}$ chromosome deletions in AZF regions and male infertility was first documented in $1976^{(\mathbf{1 4})}$.Partial AZFc deletions were identified, with gr/gr deletion as the most common $^{(\mathbf{1 5})}$. The prevalence and effect of the deletion is variable according to the ]

ethnic and geographic origin of the study population $^{(\mathbf{1 0})}$.
In the current study; microdeletions were found in $9.59 \%$ of azoospermic men, which is less than that previously reported in Egyptian studies; $15 \% \%^{(\mathbf{1 6})}, 39.3 \%^{(\mathbf{1 7})}$, $20.4 \%^{(\mathbf{1 8})}$, and $10.3 \%^{(\mathbf{1 9})}$. These differences may be related to different inclusion criteria, sample size and the used technique.

Complete AZFc deletion was found in $2.05 \%$ of theazoospermic men. This was higher than previously reported in Germany $(1 \%)^{(\mathbf{2 0})}$, South Iran $(1.25 \%)^{(\mathbf{2 1})}$, and India $(0.97 \%)^{(\mathbf{2 2})}$. However; This prevalencewas 
less than previous studies on Egyptian azoospermic men; $5 \%^{(\mathbf{1 6})}$, and $9.2 \%{ }^{(\mathbf{1 8 )}}$; and also patients from other countries; 7.4 in a Han-Chinese population ${ }^{(23)}$, and $9.17 \%$ in Dravidian-Indian ${ }^{(24)}$.

In the present study; partial AZFc deletions were found in $7.54 \%$ of azoospermic men, with gr/gr deletion in $6.85 \%$ and $\mathrm{b} 2 / \mathrm{b} 3$ deletion in $0.69 \%$. This was near that was previously reported; gr/gr deletions in $7.6 \%$ and $b 2 / b 3$ deletions in $0.85 \%$ of azoospermic Indian men ${ }^{(25)}$, and $\mathrm{gr} / \mathrm{gr}$ deletions in $7.48 \%$ and $\mathrm{b} 2 / \mathrm{b} 3$ deletions in $5.6 \%$ in Dravidian-Indians ${ }^{(24)}$.

However; higher prevalences were previously reported: gr/gr deletions in $9.2 \%$ of azoospermic Egyptian men ${ }^{(\mathbf{1 8})}$, $\mathrm{gr} / \mathrm{gr}$ deletions in $12.5 \%$ and $\mathrm{b} 2 / \mathrm{b} 3$ deletion in $9.3 \%$ in China ${ }^{(23)}$, gr/gr deletions in $8.5 \%$ and $\mathrm{b} 2 / \mathrm{b} 3 d$ deletions in $5.8 \%$ of infertile Korean men ${ }^{(26)}$, gr/gr deletions in $10 \%$ and b2/b3 deletions in $5 \%$ of infertile men from Iran $^{(27)}$, and gr/gr deletions in $12.4 \%$ and b2/b3 deletions in $4.96 \%$ of infertile Chinese men ${ }^{(28)}$.

In a previous study on infertile men from five different locations (India, Poland, Tunisia, United States and Vietnam); Rozen and colleagues reported gr/gr deletions in $2.4 \%, \mathrm{~b} 2 / \mathrm{b} 3$ deletion in $1.1 \%$, and $\mathrm{b} 1 / \mathrm{b} 3$ in $0.1 \%$ of the studied populations (29). Anotherstudy on Italianazoospermic men documented $\mathrm{gr} / \mathrm{gr}$ deletion in $3.2 \%$ and $\mathrm{b} 2 / \mathrm{b} 3$ deletion in $0.5 \%$ of them ${ }^{(30)}$. A more recentstudyon Spanish azoospermic men demonstrated gr/gr deletion in $3.9 \%$ and $\mathrm{b} 2 / \mathrm{b} 3$ deletion in $1.3 \%$ of patients ${ }^{(\mathbf{3 1})}$.The variation in the frequency may be related to genetic background, ethnic variation and $\mathrm{Y}$ haplotypes.

In the present study; the difference in testicular volume between azoospermicpatients with AZF deletions and azoospermic men without deletionswas not significant. This is in accordance with a previous report ${ }^{(\mathbf{1 9})}$. This finding implied that AZF microdeletions in infertile patients are not related to the testicular volume.

In the current study; there was no significant difference in the serum levels of
FSH, LH, testosterone and prolactinbetweenazoospermic men with and without AZF deletions. These findings are

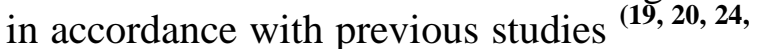
32, 33). These results implied that AZF microdeletions in azoospermicpatients were not be related to the levels of reproductive hormones.

To the contrary; in a previous study; the serum levels of FSH and testosterone were significantly lower in patients with microdeletion, while serum level of LH was significantly higher in patients with microdeletions ${ }^{(34)}$. This may be related todifferent inclusion criteria.

This study provided further evidence that partial deletions of the AZFc region are a risk factor for NOA. Several partial deletions of $\mathrm{AZFc}$ were found to be associated with impaired spermatogenesis, suggesting multiple genes related to this process are located in this region. These findings reinforce the necessity of AZF microdeletion testing among infertile males prior to employment of assisted reproduction techniques.

\section{REFERENCES}

1. Aziz N: The importance of semen analysis in the context of azoospermia.Clinics (Sao Paulo). 2013; 68 Suppl 1: 35-8.

2. Esteves SC, Miyaoka $R$ and Agarwal A: An update on the clinical assessment of the infertile male. [corrected].Clinics (Sao Paulo). 2011; 66(4): 691-700.

3. Kumar R: Medical management of nonobstructive azoospermia.Clinics (Sao Paulo). 2013; 68 Suppl 1: 75-9.

4. Hotaling $\mathbf{J}$ and Carrell DT: Clinical genetic testing for male factor infertility: current applications and future directions.Andrology. 2014; 2(3): 33950 .

5. Calafell $F$ and Larmuseau MHD: The Y chromosome as the most popular marker in genetic genealogy benefits interdisciplinary research.Hum Genet. 2017; 136(5): 559-73. 
6. Skaletsky H, Kuroda-Kawaguchi T, Minx PJ, Cordum HS, Hillier L, Brown LG, Repping S, Pyntikova T, Ali J, Bieri T, Chinwalla A, Delehaunty A, Delehaunty K, Du H, Fewell G, Fulton L, Fulton R, Graves T, Hou SF, Latrielle P, Leonard S, Mardis E, Maupin R, Mcpherson J, Miner T, Nash W, Nguyen C, Ozersky P, Pepin K, Rock S, Rohlfing T, Scott K, Schultz B, Strong C, Tin-Wollam A, Yang SP, Waterston RH, Wilson RK, Rozen S and Page DC: The malespecific region of the human $\mathrm{Y}$ chromosome is a mosaic of discrete sequence classes.Nature. 2003; 423(6942): 825-37.

7. Li Z, Haines CJ and Han Y: "Microdeletions" of the human Y chromosome and their relationship with male infertility.J Genet Genomics. 2008; 35(4): 193-9.

8. Malekasgar AM and Mombaini $\mathrm{H}$ : Screening of ' $\mathrm{Y}$ ' chromosome microdeletions in Iranian infertile males.J Hum Reprod Sci. 2008; 1(1): 29.

9. Suganthi R, Vijesh VV, Vandana $\mathbf{N}$ and Fathima Ali Benazir J: Y choromosomal microdeletion screening in the workup of male infertility and its current status in India.Int $J$ Fertil Steril. 2014; 7(4): 253-66.

10. Krausz $C$, Hoefsloot $L$, Simoni $M$ and Tuttelmann F: EAA/EMQN best practice guidelines for molecular diagnosis of Y-chromosomal microdeletions: state-of-the-art 2013. Andrology. 2014; 2(1): 5-19.

11. Krausz $C$ and Casamonti $E$ : Spermatogenic failure and the $\mathrm{Y}$ chromosome.Hum Genet. 2017; 136(5): 637-655.

12. Silber SJ: The $Y$ chromosome in the era of intracytoplasmic sperm injection: a personal review.Fertil Steril. 2011; 95(8): 2439-48.e1-5.

13. Organization WH: WHO Laboratory Manual for the Examination and Processing of Human Semen, 5th
Edition.WHO Press, Geneva, Switzerland. 2010.

14. Tiepolo $L$ and Zuffardi O: Localization of factors controlling spermatogenesis in the nonfluorescent portion of the human $\mathrm{Y}$ chromosome long arm.Hum Genet. 1976; 34(2): 11924.

15. Repping S, Skaletsky H, Brown L, Van Daalen SK, Korver CM, Pyntikova T, Kuroda-Kawaguchi T, De Vries JW, Oates RD, Silber S, Van Der Veen F, Page DC and Rozen S: Polymorphism for a $1.6-\mathrm{Mb}$ deletion of the human $\mathrm{Y}$ chromosome persists through balance between recurrent mutation and haploid selection.Nat Genet. 2003; 35(3): 247-51.

16. El Awady MK, El Shater SF, Ragaa E, Atef K, Shaheen IM and Megiud NA: Molecular study on Y chromosome microdeletions in Egyptian males with idiopathic infertility.Asian $J$ Androl. 2004; 6(1): 53-7.

17. Elhawary N, Seif-Eldin N, Zaki M, Diab H, Teama $S$ and Saleh S: Common Tag STSs in the AZF region associated with azoospermia and severe oligospermia in infertile Egyptian men.Open Androl J. 2010; 2(1): 11-8.

18. Fayez A, El-Sayed A, El-Desouky M, Zarouk W, Kamel A, Fahmi I and EIRuby M: Molecular characterization of some genetic factors controlling spermatogenesis in Egyptian patients with male infertility. Int $J$ Infertility Fetal Med. 2012; 3(3): 69-77.

19. Hussein TM and Elneely DI: Ychromosome microdeletions and the MTHFR C677T polymorphism in Egyptian men with nonobstructive azoospermia.Hum Androl. 2014; 4(3): 66-70.

20. Simoni M, Tuttelmann F, Gromoll J and Nieschlag E: Clinical consequences of microdeletions of the Y chromosome: the extended Munster experience.Reprod Biomed Online. 2008; 16(2): 289-303.

21. Masoudi R, Mazaheri-Asadi $L$ and Khorasani S: Partial and complete 
microdeletions of $\mathrm{Y}$ chromosome in infertile males from South of Iran.Mol Biol Res Commun. 2016; 5(4): 247-255.

22. Bansal SK, Jaiswal D, Gupta N, Singh K, Dada R, Sankhwar SN, Gupta G and Rajender S: Gr/gr deletions on Ychromosome correlate with male infertility: an original study, metaanalyses, and trial sequential analyses.Sci Rep. 2016; 6: 19798.

23. Lu C, Zhang J, Li Y, Xia Y, Zhang F, Wu B, Wu W, Ji G, Gu A, Wang S, Jin $L$ and Wang $X$ : The b2/b3 subdeletion shows higher risk of spermatogenic failure and higher frequency of complete AZFc deletion than the gr/gr subdeletion in a Chinese population.Hum Mol Genet. 2009; 18(6): 1122-30.

24. Vijesh VV, Nambiar V, Mohammed SI, Sukumaran $S$ and Suganthi R: Screening for AZFc partial deletions in Dravidian men with nonobstructive azoospermia and oligozoospermia.Genet Test Mol Biomarkers. 2015; 19(3): 1505.

25. Shahid M, Dhillon VS, Khalil HS, Sexana A and Husain SA: Associations of Y-chromosome subdeletion gr/gr with the prevalence of Y-chromosome haplogroups in infertile patients.Eur $J$ Hum Genet. 2011; 19(1): 23-9.

26. Choi J, Song SH, Bak CW, Sung SR, Yoon TK, Lee DR and Shim SH: Impaired spermatogenesis and $\mathrm{gr} / \mathrm{gr}$ deletions related to $\mathrm{Y}$ chromosome haplogroups in Korean men.PLoS One. 2012; 7(8): e43550.

27. Motovali-Bashi M, Rezaei $Z$, Dehghanian F and Rezaei H: Multiplex PCR based screening for micro/partial deletions in the AZF region of $\mathrm{Y}$ chromosome in severe oligozoospermic and azoospermic infertile men in Iran.Iran J Reprod Med. 2015; 13(9): 563-70.
28. Wang YM, Li Q, Song LB, Zhang JY, Yang $J$ and Song NH: [Association of the deleted DAZ gene copy related to $\mathrm{gr} / \mathrm{gr}$ and b2/b3 deletions with spermatogenic impairment].Zhonghua Nan Ke Xue. 2016; 22(1): 17-21.

29. Rozen SG, Marszalek JD, Irenze K, Skaletsky H, Brown LG, Oates RD, Silber SJ, Ardlie $K$ and Page DC: AZFc deletions and spermatogenic failure: a population-based survey of 20,000 Y chromosomes.Am J Hum Genet. 2012; 91(5): 890-6.

30. Giachini C, Laface I, Guarducci E, Balercia G, Forti $G$ and Krausz C: Partial AZFc deletions and duplications: clinical correlates in the Italian population.Hum Genet. 2008; 124(4): 399-410.

31. Lo Giacco D, Chianese C, SanchezCurbelo J, Bassas L, Ruiz P, Rajmil O, Sarquella J, Vives A, Ruiz-Castane E, Oliva R, Ars E and Krausz C: Clinical relevance of Y-linked CNV screening in male infertility: new insights based on the 8-year experience of a diagnostic genetic laboratory.Eur J Hum Genet. 2014; 22(6): 754-61.

32. Liu W, Gao X, Ma G, Yan L, Chen T, Li T, Yu RM and Ma JL: Correlation of genetic results with testicular histology, hormones and sperm retrieval in nonobstructive azoospermia patients with testis biopsy.Andrologia. 2016.

33. Zhang YS, Dai RL, Wang RX, Zhang ZH, Fadlalla $E$ and Liu RZ: Azoospermia factor microdeletions: occurrence in infertile men with azoospermia and severe oligozoospermia from China.Andrologia. 2014; 46(5): 535-40.

34. Abid S, Maitra A, Meherji P, Patel Z, Kadam S, Shah J, Shah R, Kulkarni V, Baburao V and Gokral J: Clinical and laboratory evaluation of idiopathic male infertility in a secondary referral center in India.J Clin Lab Anal. 2008; 22(1): 29-38. 
SOHAG MEDICAL JOURNAL MOLECULAR GENETIC AND LABORATORY FINDINGS 